\title{
Financial Inclusion, ICBT and the Role of ICT in COMESA
}

\author{
Angella Faith Lapukeni \\ Reserve Bank of Malawi, Malawi \\ Maestros Leadership Company, Malawi
}

Copyright (C) 2015 by authors, all rights reserved. Authors agree that this article remains permanently open access under the terms of the Creative Commons Attribution License 4.0 International License

\begin{abstract}
The unbanked are not financially inactive and neither do they consume all of their income. One of the reasons financial inclusion has become a policy priority is because of the negative macro-economic y consequences of the informal sector, which includes an informal financial system and informal trade. Informal Cross Border Trade (ICBT) is prevalent in Africa and particularly in the Common Market for Eastern and Southern Africa (COMESA) region. This has negative impact on trade and other macro statistics for member economies and the region as a whole. Financial inclusion is a possible channel towards formalisation of these firms. The paper further discusses the role of developments in Information and Communications Technology (ICT) in reaching out to the financially excluded. Trend analysis shows a strong correlation between developments in ICT and Intra-Regional Trade in COMESA. The paper is a preliminary, non-technical discussion.
\end{abstract}

Keywords Financial Inclusion, Informal Cross Border Trade, Information and Communications Technology, COMESA

\section{Introduction}

The world's financially excluded population is certainly financially active and although they do not use formal, regularised financial institutions, it does not mean they do not borrow, save or invest. Individuals, households and firms who are not financially included do not necessarily consume all their income but are active in a parallel economy all together. Financial inclusion is increasingly recognized as fundamental for development as it can help poor households improve their lives while also spurring inclusive economic growth. The positive effects that are associated with financial inclusion are the advantages of network effects for participants, the expanding value of the overall financial system, and a more effective monetary policy resulting from a greater participation [1]. According to Merhotra et al. [2] financial inclusion is thought to be a "quasi-public good" as it meets the conditions of non-rivalness in consumption and non-excludability to a large degree.

\section{The Concept of Financial Inclusion}

There is no universally accepted definition on financial inclusion. It is usually defined as the proportion of individuals and firms that have access to or use financial services [3]. Burkett and Sheehan [4] define financial exclusion as:

A process whereby a person, group or organisation lacks or is denied access to affordable, appropriate and fair financial products and services, with the result that their ability to participate fully in social and economic activities is reduced, financial hardship is increased, and poverty (measured by income, debt and assets) is exacerbated.

According to World Bank [35] financial inclusion includes four vital areas: savings, credit, transaction banking, and insurance. Consequences of financial exclusion will vary depending on the nature and extent of services denied. However the potential costs of incomplete participation in the financial system are still not explicitly addressed in the literature. Financial exclusion imply that poor people must rely on their own limited savings to invest in education or become entrepreneurs and small enterprises must rely on their limited earnings to pursue promising growth opportunities. Financial exclusion therefore can contribute to persistent income inequality and slower economic growth [27]. Ironically, the most frequently cited reason for not having a formal account in Africa is lack of enough income.

Extending financial services to a population has both macro and micro implications, largely positive. A considerable amount of literature attests that financial inclusion causes economic growth overall financial development, and poverty reduction, and can improve income distribution and human development [32]. Further, financial inclusion boosts inclusive growth as it increases shared prosperity. Various empirical literature have found consistent results of the benefits of financial inclusion. For 
example Burgess and Pande, (2003) in India found that a one per cent increase in the number of rural bank branches led to a drop in poverty of $0.34 \%$ and an increase in output of $0.55 \%$; Beck et al (2004) find that a more inclusive financial system reduces income inequality and poverty; People with access finance are more likely to increase consumption, productivity and income and manage shocks [28]. Goodwin et al (2012) in a study conducted in Britain, states that financial exclusion is clearly associated with poverty and deprivation. Similarly, some studies suggest that increased access to microcredit enhances investment and entrepreneurship for households with existing businesses ([20], [39]).

Governments, banks and financial regulators all over the world have thus set up new initiatives for financial inclusion and new legislative regulations have been initiated. An example is Kenya where regulation and supervision has evolved to keep pace with innovations in the market place. The country has mobile payments such as M-Pesa, M-Kesho, Pesa-Pap, M-Shwari, KCB Mtaani and Faulu Popote which integrate the mobile phone payment platform with the banking sector [30]. By September 2014, Kenya had 9 deposit taking microfinance (DTM) institutions with 96 branches. Such examples are few cases that are curbing heavy branch regulation which is one of the factors that restrict the geographical expansion of bank branches in Africa. However efforts to foster inclusion must be well designed so as not to compromise financial stability. Regulators have the tough duty of balancing both innovation and prudent regulation [31].

\section{Financial Inclusion: Globally, In Africa and the COMESA Region}

Financial exclusion worldwide is still prevalent. Most financial inclusion data is survey data such as the Global Findex data of the World Bank. As of 2011, the dataset reported that half of the adult population in the world, 2.5 billion people, were 'unbanked'. This means that they do not have access to a bank account at a formal financial institution [5]. This figure reduced to 2 billion however as of the 2014 surveys as shown in Figure 1 [6]. This is a signal of ongoing global policy of financial inclusion.

Financial systems in Africa are still generally lagging behind those in other developing economies (Figure 1). Africa is the second lowest region in the globe in terms of adults with a bank account. Overall, $34 \%$ of adults in the Africa region had an account as of 2014 [6]. As of 2011, within Africa, there was a large variation in account ownership: ranging from $51 \%$ in Southern Africa to $11 \%$ in Central Africa [5]. The low level of financial inclusion in Africa is reflected in constraints on both the demand and the supply side of the economy. Existing financial systems are underdeveloped, credit reporting from financial institutions is lacking and the level of financial literacy is often poor. Financial inclusion is further limited by low-quality financial infrastructure and the small size of many African economies.

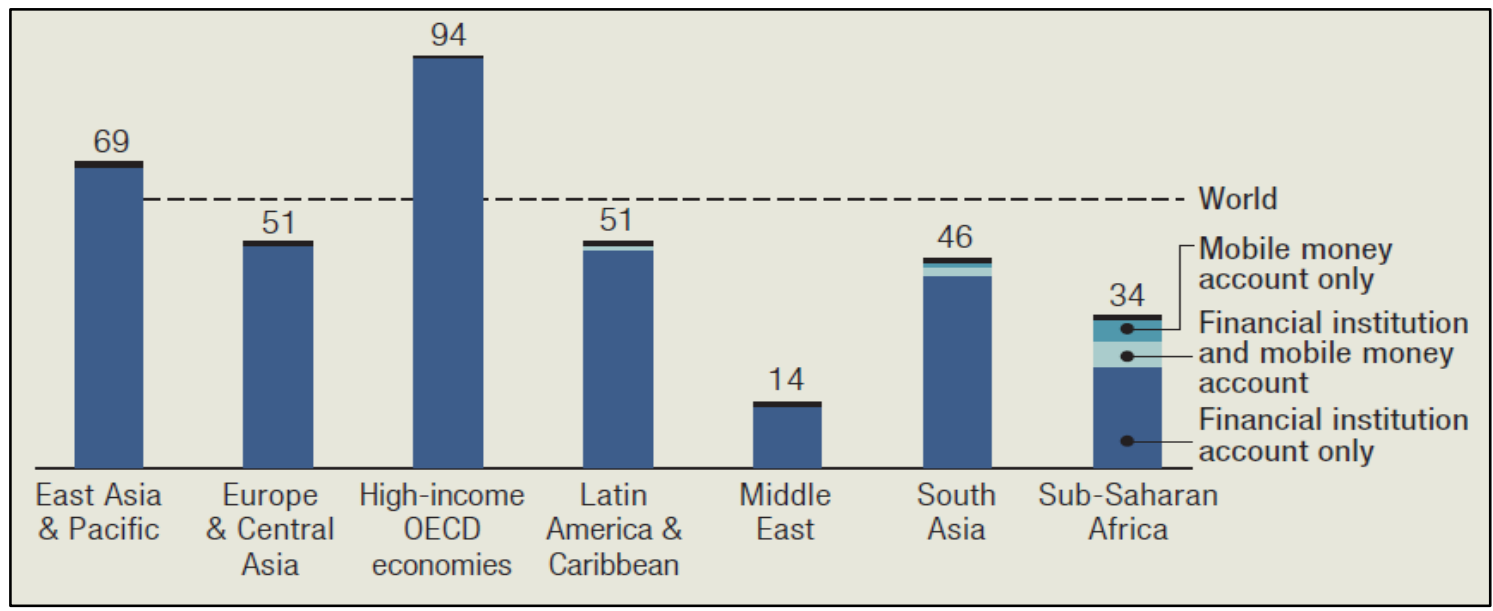

Source: [6]

Figure 1. Adults with an account at a formal financial institution 2014 (\%) 


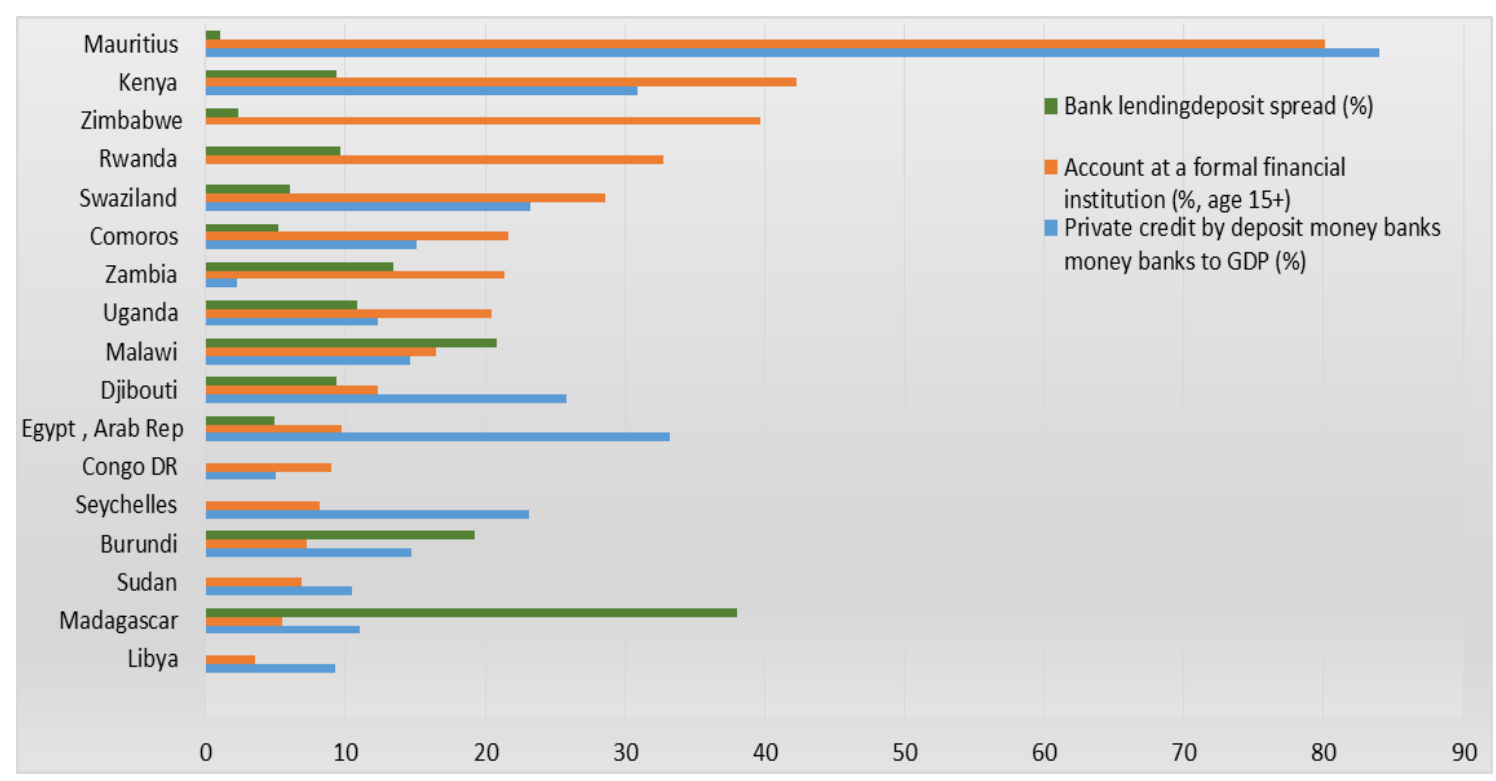

Source: [3] and Author computations

Figure 2. Financial Inclusion in COMESA Countries, Averages, 2009-11

COMESA is a huge regional market in Africa, accounting for 35 percent of the 54 countries on the African continent. COMESA's total geographic area of 11.6 million square $\mathrm{km}$ covers 38 percent of the African continent; and its population of 444 million inhabitants (in 2011) accounts for 43 percent of Africa's total population. Financial inclusion varies widely within the COMESA Region (Figure 2), with 3.5 percent being the lowest proportion of adults (age 15 and above) with an account at a formal financial institution (Libya) and 80.1 percent being the highest (Mauritius) in terms of averages between 2009 and 2011 [3]. As of 2014, the region average of adults with a bank account was 19.2 percent and 31.8 percent, a significant improvement from 19.2 percent in 2011. Mauritius had the largest number of adults with a bank/mobile account at 82.2 percent of the adult population whilst Burundi was the lowest with 7.1 percent [6]. Formal financial services are dominated by banks with deposits being more common than loans.

One of the challenges faced by member countries in the implementation of macro-economic convergence criteria in COMESA is undiversified nature of the financial markets and instruments and weak monetary transmission mechanisms. Financial inclusion may improve both of these obstacles. On the latter, increased financial inclusion ensures more effective monetary policy because it increases the reach of the policy. On the former, more participation is likely to increase the demand for diversified instruments thus contributing to improvement in the financial markets of member states. Absence of a secure and reliable payment infrastructure within the COMESA region can hinder development of the market. This is the reason the Regional Payment and Settlement System (REPSS) was introduced. REPSS allows member countries to transfer funds more easily within COMESA with the main aim of stimulating economic growth through an increase in intra-regional trade. The system operates through member countries' central banks and their corresponding banking systems. However, this requires the importer/exporter to use their respective commercial banks. If the adult population of member countries are still functioning outside the regulated financial system, then efforts of a system as beneficial as REPSS may prove futile and its reach will be limited.

\section{ICBT: Definition, Benefits and Challenges to the Economy}

The informal economy is multi-faceted with different markets and engages in varied activities. It can include informal labour markets, informal financial sectors and informal corporate or business sectors. Researchers have found it difficult to come up with a precise single definition of informality. The informal sector is the part of the economy, which is characterised by entrepreneurs operating without licences or titled property rights and doing family-based businesses that do not generate taxes [7]. Another definition by Batini et, al [22] defines informality as economic activities that are neither taxed nor monitored by the government. This paper will focus on informal corporate or business sector that is engaged in informal cross border trade (ICBT). The informal sector is likely to grow at a faster rate if the formal sector and public policies are inefficient. For purposes of this paper, (ICBT) is generally defined as an economic activity that is legal but unregulated, and refers to unrecorded business transactions undertaken across the borders [8]. It includes goods moved through unofficial and official trade routes (through under-invoicing and mis-declarations of cargo).

Majority of micro, small and medium enterprises in the developing world operate in the informal economy. Most small and marginalised enterprises are often clandestine, unregistered and operated by the individuals who hold assets 
without property rights or representations which the financers cannot use as assets in the market. Schneider et al. [34] estimates the informal sector to be around 40-50 percent of official GDP. The majority of the African economies remain reliant on cash, implying that the population still have their trust in physical money (although Chipeta [9] makes mention of indigenous/informal commodity money but this is less likely across borders). On the other hand, informal economies can potentially play a positive role, especially in developing countries where they may be viewed as the nursery of future economic growth in the formal economy. In economies and business environments hindered by overly excessive barriers and poorly designed regulations, informality can provide an alternative to entrepreneurs and small firms. Further, in a country with high barriers to trade that prevents affordable import of foreign goods, these create incentives for smuggling and an informal market for the barred products. In such situations, the absence of an informal sector can result in a far greater waste of resources. If costs to start and run a business are binding, the informal sector can benefit firms to grow to be successful formal sector firms by helping them avoid excessive costs of being formal (e.g. taxes, pension contributions, and minimum wages).

However, to date, there is still limited information on the dimension of ICBT as the tools for its measurement have not been very well developed. The situation has had some adverse impact on the estimation and reporting of intra-African trade and under estimated figures in national trade statistics. GDP could be far greater if the potential enterprises of the informal sector could also be included. The average contribution by SMEs to GDP in the COMESA region is estimated at 20-25 percent, with a minimum and maximum contribution of 12 percent and 39 percent attributed to Sudan and Malawi respectively [10]. This paper argues that increase in financial inclusion in the COMESA economic region will reduce informal trade and increase intra-regional trade in COMESA through the benefits that financial inclusion makes available to businesses as discussed herein.

\section{Challenges facing Informal Traders}

Informal firms face a variety of constraints, making it harder for them to do business and grow. Informal firms claim lack of access to finance as the most important barrier they face in their operations [11].The main barriers to access to formal financial accounts are costs, distances and bureaucracy [3]. Thus one of the greatest needs of informal traders is improved access to financial services-not just loans, but savings, insurance, payments, pensions, and other products. When coupled with related nonfinancial services, such as consumer awareness, training, and market information, it can lead to breakthrough opportunities for people who have had limited economic avenues. The region's small and medium enterprises are a key driver of growth and jobs in the private sector [12]. The majority of the SMEs that were interviewed during the profiling exercise that was undertaken by the COMESA Secretariat considered the shortage of suitable finance and use of old and rudimentary equipment as a major constraint that has hampered the production of quality products and productivity [10].

\section{The Financial Inclusion Solution to ICBT}

Cross-country studies have shown that countries with more developed formal financial systems record faster declines in income inequality and poverty levels [13]. Besides the broader impact on growth and redistribution for poor people, access to credit, savings and payment services provides opportunities to increase their income through three channels. These are new economic opportunities, better management of risk and exchange of goods and services. In many instances, informal trade represents the only type of exchange that is possible under conditions prevailing in some regional economic communities. Poor regional infrastructure and communications often render near-impossible "official" trade between neighbouring countries. In Africa, intra-Africa trade is quite diversified compared with Africa's trade with the rest of the world, a large part of which is informal cross border trade (ICBT).

The banks/financial institutions are not inclined to grant credit facilities to SME's because the units are in the informal sector and the owners/promoters of these enterprises are not in a position to provide the comfort of collateral security to the banks. Banks are not as common a source of financing among informal firms. Use of loans and bank accounts for business by informal firms is very low and a significant majority of firms finance their day-to-day operations and investments through sources other than financial institutions (internal funds, moneylenders, family and friends). On the one hand, financial services may contribute to facilitate trade flows, to reduce their cost and to maximize their developmental impact.

On the other hand, increased trade expand the demand for financial services and policy makers have to have infrastructures in place to accommodate that demand. Also increased financial inclusion means increased access to credit, a process that will attract more entrepreneurs to take up business opportunities and increase trade. Increased trade will further increase demand for financial services and so on. Enhancing the financial inclusion of informal firms interested in registering can potentially help them grow and pave their path toward formalization. The availability of credit can also enable microenterprises to improve their production capacities as well as production efficiency, as well as hire more skilled workers and generate higher revenues and profits. In the process, they will also be exposed to credit products from the formal sector. 


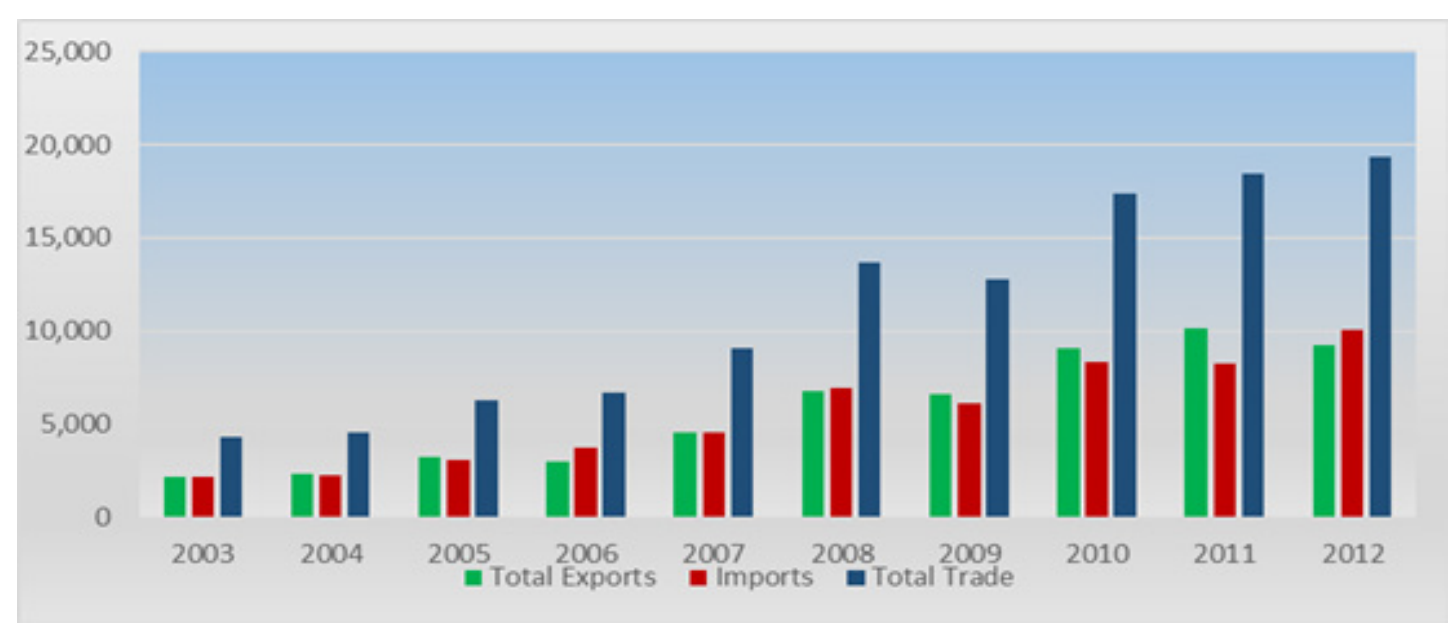

Source: [10]

Figure 3. Intra-COMESA Trade, 2003-2012 (Value in US \$ million)

The existence of ICBT directly implies the existence of an informal financial sector in African countries. According to Chipeta \& Mkandawire [25] the informal financial sector consists of those financial transactions which are not directly responsive to the control by monetary authorities. This is mostly characterised by savings groups and credit associations consisting of people with similar commercial objectives, such as traders; similar religious beliefs, in the case of Christian and Muslim organisations; or social or youth clubs, town unions and moneylenders. Economies with less developed credit markets tend to have more informal credit markets [22]. In many African countries, most people in the middle- and lower-income brackets use informal or semi-formal savings clubs, associations and co-operatives to save money and access credit when necessary. For instance, in Sub-Saharan Africa, 34\% of those who save had reported having only used a community based savings club in the past 12 months [27].

Informal schemes can provide savings facilities and credit to poorer people at cheaper and more favourable terms than those of formal financial institutions. In patronising informal financial institutions, people do not have to try to comply with the requirements necessary to open up savings or credit accounts at formal financial institutions. Informal financial institutions also do not require collateral, which gives them an advantage over formal financial institutions. These institutions deserve attention and consideration in policy making. Some examples include smaller-scale group arrangements such as savings groups, mutual aid associations, non-rotating savings and credit associations (SCAs), rotating savings and credit associations (ROSCAs). These are known for not putting together people with too different backgrounds and interests. The size limitation restricts the usage of the resources to those borrowers whose demand for loans is not regular (e.g. those requiring loans to purchase a relatively expensive consumption item). This has adverse implications however for financial market development and integration, and for the effectiveness of financial and monetary policy. A higher percentage of savings by community method is correlated to a lower level of human development. This agrees with the notion that financial inclusion improves human development [32].

Figure 3 shows the increasing trend in intra-COMESA Trade. These however are certainly missing the big proportion of informal trade that takes place across the borders. The presence of informal economy represents wastage and significant leakages from the circular flow of income, in the region. The fate of millions of potential entrepreneurs is trapped in a vicious circle of exclusion and they are unable to reap the fruits of integration in the region and globalisation, due to the inadequacy of access to the formal financial institutions. However, the existence of REC's such as COMESA are likely to cause the decrease of ICBT as barriers to international trade within such a region are minimised thus decreasing incentives to smuggle or trade informally.

\section{Towards a more Financially Inclusive COMESA}

A first step to achieve required scale to increase access and reduce costs is to promote an enabling environment. As the speed of payments increases in domestic environments, banks, corporates, and consumers have come to expect faster and more efficient payments across borders. Increased financial inclusion will allow access and more affordable use of formal trade and thus likely reduce informal trade. Financial exclusion means the use of initiatives in the region such as the COMESA Clearing House that was established for the facilitation of the settlement of trade and services payments amongst Member States will be undermined.

Previous studies suggest that the level of economic development, population density, infrastructure, outreach of bank branches, banks' overhead costs, and institutional capacity are important determinants of financial development. Higher income levels lower the barriers to 
financial inclusion and economic development and population density capture the effect of income and market size on the provision of financial services [14]. More densely populated areas should be easier to supply with financial services since infrastructure tend to be more widespread in these areas. Bank branches in densely populated areas are able to reach a larger number of customers, suggesting greater chances of being profitable and thus higher likelihood to be present.

Infrastructure is also deemed a determinant of financial inclusion since underdeveloped infrastructure makes it more expensive for financial institutions to provide their services. This may in turn have a negative impact on business activities since customers are more likely to face higher transaction costs, thus reducing the overall demand for financial services. Furthermore, since costs and distances are some of the main barriers to financial inclusion, the outreach of bank branches are assumed to be an important determinant of the outreach of the financial sector [14]. Moreover, institutional capacity, captured by a strong and well-regulated banking sector, is assumed to dampen the effect of macroeconomic shocks (or even prevent them). This suggests a positive relationship between measures of institutional development and financial inclusion [12].

\section{The Role of ICT}

There has been rapid growth in Information
Communication Technology (ICT) in recent years. Figure 4 shows a consistent upward trend in Africa in various ICT development indicators. Financial inclusion is one of the channels through which ICT affects growth thus it can contribute to growth of member countries. Previous work by $[15,14]$, investigate which factors determine the outreach of the financial system. Their findings suggest that level of economic development, as well as population density and financial stability are of particular importance for financial inclusion. They further conclude that electricity consumption and mobile phone diffusion have positive effects on financial access.

ICTs allow for greater financial inclusion, and the financial services sector is a primary driver of communications and network technology. Technology developments such as telecommunication infrastructure and more advanced payment systems do not only reduce transaction costs but also expand reachable areas. It is striking to see the role that ICT and innovative business models have played in the explosive growth of financial inclusion. Innovative use of ICT has made management of large numbers of small transactions easier and the delivery of financial services in remote areas cheaper. Africa's recent surge in mobile phone penetration looks promising for future progress towards greater financial inclusion [18]. Between 2002 and 2010, the number of mobile phone subscriptions increased from 18 million to more than 400 million (approximately $70 \%$ of the population) although only $20 \%$ of these people have access to formal financial services [19].

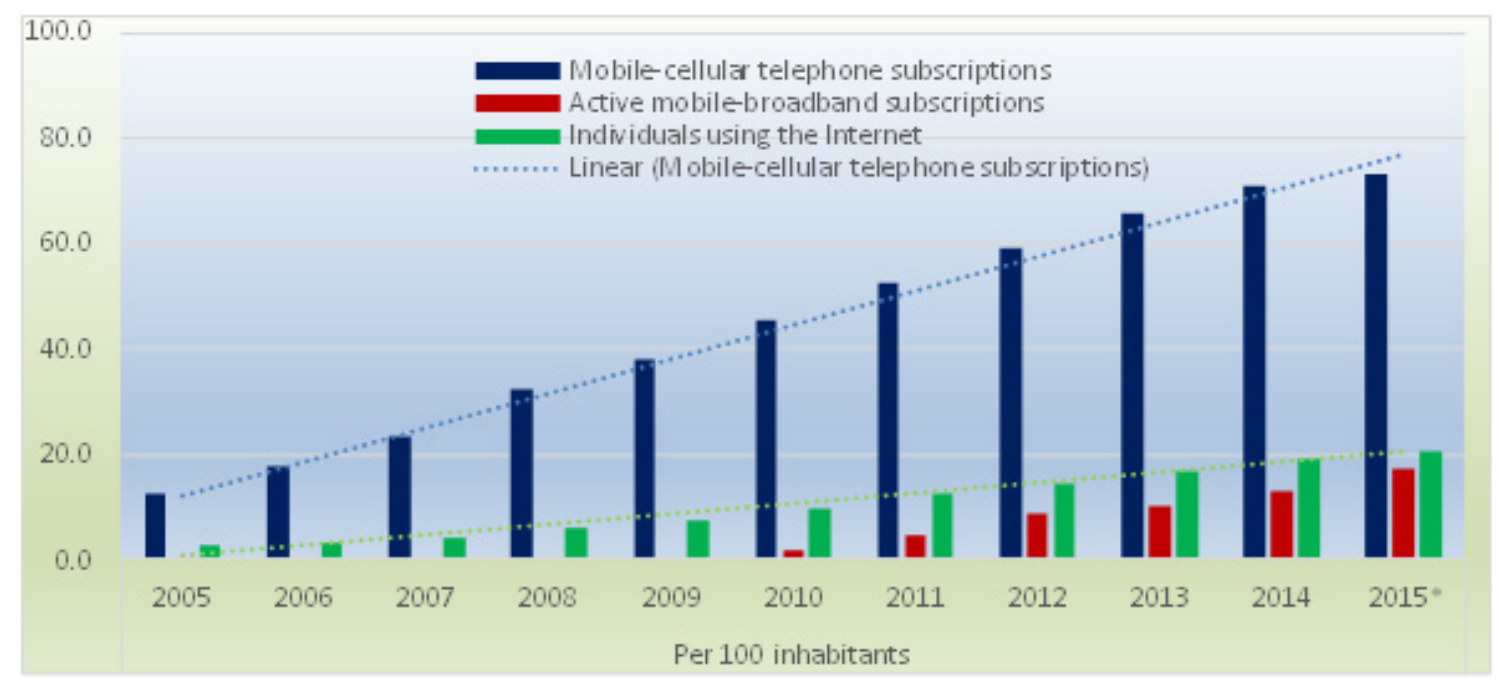

Source [16]; Data on active mobile-broadband subscriptions only available from 2010

Figure 4. Growth in selected ICT Indicators in Africa per 100 Inhabitants 


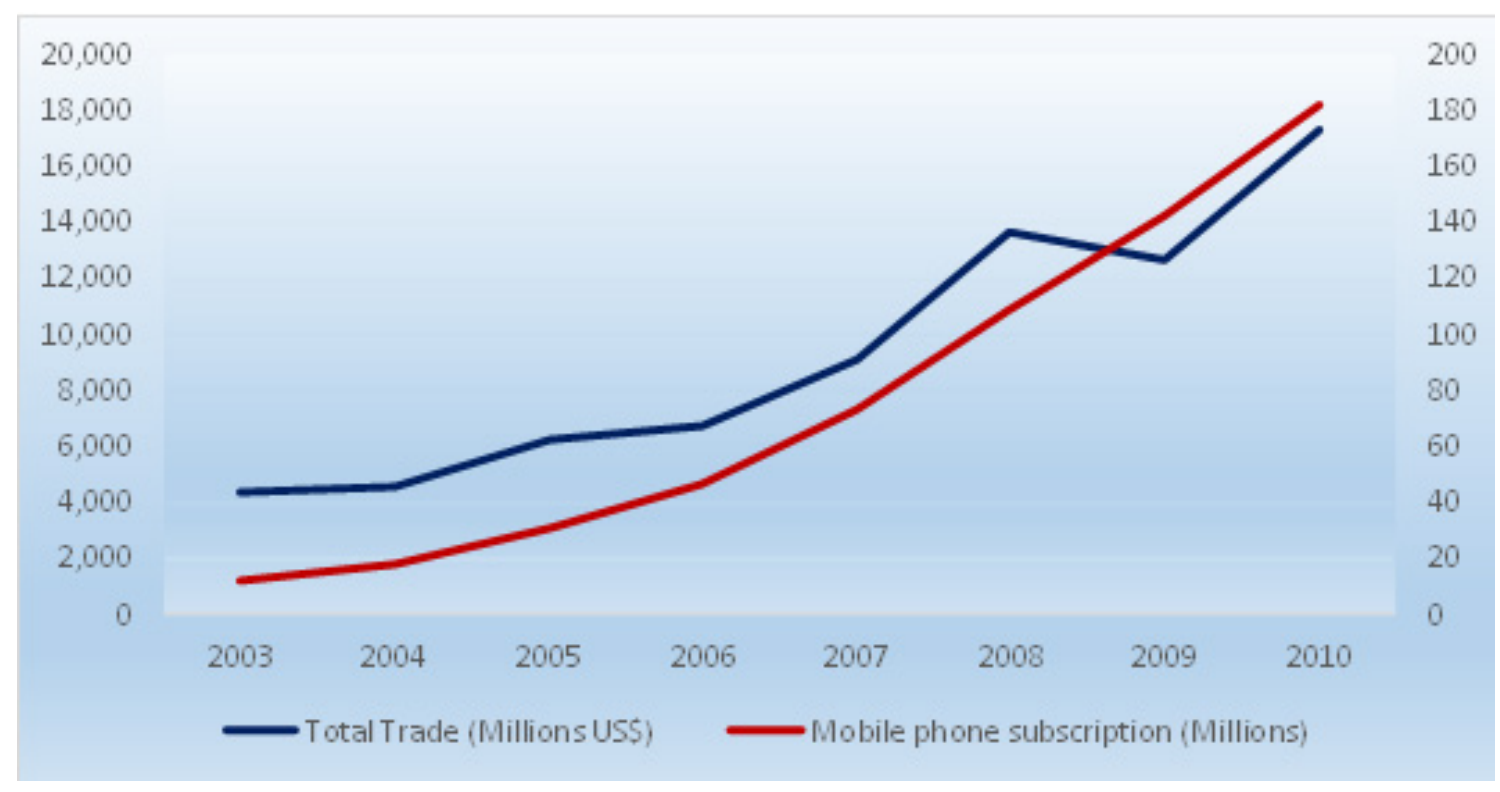

Source: [17]

Figure 5. COMESA Intra Regional Trade and Mobile Phone Subscription in COMESA countries

Trends in Figure 5 show high correlation between intraregional trade in the COMESA region and mobile phone subscription. There is a 98 percent correlation between the two variables. Already, ICT is one of the areas of focus for the COMESA region. The correlation results may not mean causation however but does leave room for further research.

The development of technological innovations and new business models can facilitate overcoming several of the structural obstacles that affect the supply and demand for financial services. The catalytic role of technology and innovative business models to facilitate financial inclusion can help reach areas previously unserved due to the high cost of operating a bank branch. Technology can make it feasible to reach an even broader population and can help expand operations in remote or sparsely populated rural areas. The delivery of financial services through digital channels, in particular through mobile, offer the greatest potential for reducing the costs of reaching a broader population and expanding operations in remote areas, while also enhancing the convenience of accessing the services, thereby tackling two of the main obstacles limiting financial inclusion. Indeed, the experience of countries where digital payments are more widely available suggests that this can be certainly a relevant and fast way of expanding access to financial services.

For example, efforts by many countries in the use of non-banking correspondents or agents have improved physical coverage. For instance, Alliance for Financial Inclusion [29] documents that the Bank of Tanzania, started to encourage the market to offer more broad mobile financial services, including micro-savings, micro-insurance, micro-loans, and even credit history information. This may be part of the reforms that have seen more than US\$ 4.3 billion of MFS transactions made since the country introduced MFS in 2007 (equivalent to $40 \%$ of the country's annual GDP). The authors also cite Kenya's M-PESA agents handle over US\$ 30 million of transactions daily. The regulatory framework for COMESA as a whole however is still wanting in embracing these innovations as these examples are exceptional to these countries.

\section{Conclusion and Policy Implications}

This paper is a non-technical discussion on the impact of financial inclusion on ICBT and the role ICT can play in improving financial inclusion, especially for informal traders in Africa. The paper discussed potential benefits of financial inclusion for any economy and for the COMESA region in particular where ICBT is prevalent. As access to finance is the biggest challenge faced by informal firms, financial inclusion will reduce this problem and also help informal firms towards formalisation. Financial inclusion can certainly facilitate financial integration for the region and consequently lead to formalisation of informal firms thereby improving intraregional trade. The latter may improve as more trade will be recorded even if it may not have necessarily increased. This is likely to better the accuracy of trade statistics in the region by the reduction of the informal trade sector and thus better inform policy makers. Furthermore, financial inclusion will enable more people to engage in business through access to cheaper credit than that of the informal sector and thus may further increase intra-regional trade. Further study is to be done to establish the empirical relationship between financial inclusion, ICBT and ICT.

It is noteworthy that data on ICBT is lacking by the very nature of it and data on financial inclusion is mainly survey data that has been collected starting in recent years. This makes the analysis somewhat challenging. Nevertheless, promotion of ICT for the purpose of improving financial 
inclusion is likely decrease ICBT in the COMESA region. Further attention needs to be placed on financial inclusion in the region not only due to the microeconomic but also macro benefits to the economy. With a more financially included COMESA, financial integration will better accelerate and consequently, better improvements in intra-regional trade.

\section{Acknowledgements}

This paper is an improved and extended version of the paper presented by the author at the International Business, Economics, Finance and Management (BREFM) Conference, Hokkaido, Japan. 20-22 July 2015.

\section{REFERENCES}

[1] Agrawal, A, 2008, The need for financial inclusion with an Indian perspective, Economic Research, IDBI, Mumbai

[2] Merhotra, N., V. Puhazhendhi, G. N. Gopakumaran, \& Sahoo, B.B, 2009, Financial Inclusion - an overview, Department of Economic Analysis and Research - National Bank for Agriculture and Rural Development, Mumbai.

[3] World Bank, 2014, Global Financial Development Report 2014: Financial Inclusion, International Bank for Reconstruction and Development / The World Bank, Washington

[4] Burkett, I and Sheehan, G. 2009. "From the margins to the mainstream: The Challenges for microfinance in Australia" Brotherhood of St Laurence and Foresters Community Finance.

[5] Demirgüç-Kunt, A., \& Klapper, L, 2012, Measuring Financial Inclusion: The Global Findex, World Bank Policy Research Working Paper Series 6025.

[6] Demirguc-Kunt, A., Klapper,L., Singer, D.,Van Oudheusden, O. 2015. " The Global Findex Database 2014: Measuring Financial Inclusion around the World." Policy Research Working Paper 7255, World Bank Group, Washington, DC.

[7] Qureshi, S., and Trehan, K. 2014 Role of Financial Inclusion in Restraining Entrepreneurial Breakdown In India. International Journal of Core Engineering \& Management(IJCEM) Volume 1, Issue 1, April 2014

[8] Uganda Bureau of Statistics (UBOS), 2009. The informal cross border trade qualitative baseline study 2008, UBOS, September, 2009.

[9] Chipeta, C., 2012, Principals of Indigenous Economics, Fattani Offset Printers, Zomba

[10] COMESA, 2013. Foreign Direct Investment and Small and Medium Enterprise Linkages in COMESA

[11] World Economic Forum. 2010. Global Competitiveness Report 2010-2011. Geneva: WEF.

[12] Lundqvist, $M$ and Erlandsson, F. 2014. The Diffusion of Mobile Phones and its Impact on Financial Inclusion and
Economic Growth in Africa. Master Thesis, Department of Economics, Lund University

[13] Demirguc-Kunt, A. 2005. 'Financial Sector Development as an Essential Determinant for Achieving the MDGs: Increasing Private Credit Shown to Reduce Income Inequality', World Bank, Washington D.C.

[14] Kendall, Jake, Nataliya Mylenko, and Alejandro Ponce, 2010, - Measuring Financial Access around the World, II Policy Research Working Paper, No 5253 (Washington: World Bank).

[15] Beck, Thorsten, Asli Demirguc-Kunt, and Maria Soledad Martinez Peria, 2007, - Reaching Out: Access to and Use of Banking Services Across Countries, II Journal of Financial Economics, 85(1), pp. 234-66.

[16] International Telecommunication Union (ITU). 2014. Measuring the Information Society Report 2014. ITU, Geneva.

[17] COMESA, 2012. International Trade Statistics Bulletin No.11 2012

[18] Faye, I. Triki, T., \& (eds), 2013, Financial Inclusion in Africa, African Development Bank Group, Ghana, Tunisia

[19] Alliance for Financial Inclusion, 2012, The African Financial Inclusion Policy Forum: Scaling Up Financial Services Through Mobile Technology, Bangkok

[20] Banerjee, A. V., \& Duflo, E. (2011).Poor economics. New York, NY: Perseus.

[21] Barr. M. (2004). Banking the poor, Yale Journal on Regulation, 21, pp. 122-239.

[22] Batini, N. Kim, Y. Levine, P and Lotti, 2010, Informal Labour and Credit Markets: A Survey, International Monetary Fund WP/10/42

[23] Beck, T., A. Demirgüç-Kunt, and M. S. Martinez Peria. (2004). "Finance, Inequality and Poverty: Cross-Country Evidence." Journal of Economic Growth 12(1):27-49

[24] Burgess, R. \& Pande R., 2003, Do Rural Banks Matter? Evidence from the Indian Social Banking Experiment, London School of Economics and Columbia University, Columbia

[25] Chipeta, C, and M.L.C Mkandawire (1990) "The Informal Financial Sector and Macroeconomic Adjustment in Malawi.' AERC Research Paper No. 4

[26] Connolly, C. and K. Hajaj (2001). Financial services and social exclusion, financial services consumer policy centre, University of New South Wales.

[27] Demirgüç-Kunt, A., \& Klapper, L, 2012, Financial Inclusion in Africa: An Overview, World Bank Policy Research Working Paper 6088.

[28] Dupas, P., \& Robinson, J. (2011). Why don't the poor save more? Evidence from health savings experiments. NBER Working Paper 17255, Cambridge, MA: National Bureau of Economic Research.

[29] Karlan, D. \& Valdivia, M. (2011). Teaching entrepreneurship: Impact of business training on microfinance clients and institutions. The Review of Economics and Statistics, 93(2), 510-527. 
[30] M'Amanja, D,M, 2015, Financial Inclusion, Regulation and Stability: Kenyan Experience And Perspective, presentation made at UNCTAD's Multi-Year Expert Meeting on Trade, Services and Development held in Geneva, Switzerland May $11-13,2015$

[31] Triki, T., \& Faye, I. (eds), 2013, Financial Inclusion in Africa, African Development Bank Group, Ghana

[32] Hannig, A \& Jansen (2010) : Financial inclusion and financial stability: Current policy issues, ADBI working paper series, No. 259
[33] Goodwin, D., Adelman, L., Middleton, S., \& Ashworth, K., 2012, Debt, Money Management And Access To Financial Services: Evidence From The 1999 Pse Survey Of Britain, Working Paper No. 8.

[34] Schneider, F, Buehn, A and Montenegro. C,E, 2010. "Shadow Economies All over the World, New Estimates for 162 Countries from 1999 to 2007." Policy Research Working Paper 5356, World Bank, Washington DC.

[35] World Bank (2005). Indicators of financial access, household, level surveys. 